\title{
Genetically Engineered In Vitro Erythropoiesis
}

\author{
Cristopher Geiler ${ }^{1,2}$, Inez Andrade ${ }^{1}$, Alexandra Clayton ${ }^{1}$, Daniel Greenwald ${ }^{1,2}$ \\ ${ }^{1}$ Department of Basic Science Research, Cellologi, LLC, ${ }^{2}$ Santa Barbara Cottage Hospital, Santa Barbara, California, USA
}

Background: Engineered blood has the greatest potential to combat a predicted future shortfall in the US blood supply for transfusion treatments. Engineered blood produced from hematopoietic stem cell (HSC) derived red blood cells in a laboratory is possible, but critical barriers exist to the production of clinically relevant quantities of red blood cells required to create a unit of blood. Erythroblasts have a finite expansion capacity and there are many negative regulatory mechanisms that inhibit in vitro erythropoiesis. In order to overcome these barriers and enable mass production, the expansion capacity of erythroblasts in culture will need to be exponentially improved over the current state of art. This work focused on the hypothesis that genetic engineering of HSC derived erythroblasts can overcome these obstacles.

Objectives: The objective of this research effort was to improve in vitro erythropoiesis efficiency from human adult stem cell derived erythroblasts utilizing genetic engineering. The ultimate goal is to enable the mass production of engineered blood.

Methods: HSCs were isolated from blood samples and cultured in a liquid media containing growth factors. Cells were transfected using a Piggybac plasmid transposon.

Results: Cells transfected with SPI-1 continued to proliferate in a liquid culture media. Fluorescence-activated cell sorting (FACS) analysis on culture day 45 revealed a single population of $\mathrm{CD} 71^{+} \mathrm{CD} 117^{+}$proerythroblast cells. The results of this study suggest that genetically modified erythroblasts could be immortalized in vitro by way of a system modeling murine erythroleukemia.

Conclusion: Genetic modification can increase erythroblast expansion capacity and potentially enable mass production of red blood cells.

Keywords: Hematopoietic Stem Cells, Erythroblasts, Erythropoiesis, Adult Stem Cells, Erythroleukemia

\section{Introduction}

Blood transfusion demand in the US is expected to surpass donated blood collections within the next 5 years $(1,2)$. Even though significant previous research has long pre-

\footnotetext{
Accepted for publication February 23, 2016, Published online May 30, 2016 Correspondence to Cristopher Geiler

Department of Basic Science Research, Cellologi, LLC, 504 W Pueblo Street, Santa Barbara, California 93105, USA

Tel: +844-413-2552, Fax: +805-962-5277

E-mail: contact@cellologi.com

(c) This is an open-access article distributed under the terms of the Creative Commons Attribution Non-Commercial License (http://creativecommons.org/ licenses/by-nc/4.0/), which permits unrestricted non-commercial use, distribution, and reproduction in any medium, provided the original work is properly cited.
}

dicted a future shortfall in the US blood supply, an ideal solution has not been found despite decades of intense research effort (3-7). There are currently seasonal shortages (July-August) of all blood types and there is a continuous shortage of type $\mathrm{O}$ negative blood that can serve as an universal donor without risk of blood mismatch, however, only $6.6 \%$ of the population are type O- (8). In vitro engineered blood has the greatest potential to combat the future shortage and assist with seasonal fluctuations in supply. The production of engineered blood from HSCs in the laboratory has been well established in the literature (9-18). A critical barrier to the realization of engineered blood is the production scale that would be required to create the 2.5 trillion red blood cells that make up a unit of blood. 2.5 trillion is a massive number of 
cells, roughly equal to the number of fish in the ocean.

The development of the erythroid cell line from HSCs is a complicated process that is difficult to completely mimic in vitro. Erythropoiesis is regulated by several growth factors, including erythropoietin (EPO), and stem cell factor (SCF). Erythroblasts are initially highly dependent on EPO for the activation of specific erythroid genes to enable rapid proliferation as well as inhibit apoptosis (19). In the terminal stages of development, the erythroblast cells are less dependent on EPO and become more dependent on $\alpha 4 \beta 1$ integrin stimulation (20).

Development begins with erythroid lineage commitment of HSCs and the subsequent development of highly proliferative erythroid progenitor cells and ending with terminal differentiation of the mature enucleated red blood cell. The HSCs will lose the ability for self-renewal as they mature into erythroblast cells and ultimately mature erythrocytes. The first erythroid line committed progenitor cells are the most proliferative and referred to as the erythroid burst-forming unit (BFU-E) (21). The proliferative capacity of the cells decreases as they mature into subsequent erythroid colony forming units (CFU-E). Each cell division leads to serial morphological changes, committing the cell to an increasingly mature state as well as limiting the capacity for further divisions (Fig. 1). The cells will typically undergo only three to four cell divisions as they mature into morphologically distinct erythroblasts identified as proerythroblasts, basophilic, polychromatophilic, and terminating with the enucleation of the Orthochromic normoblast, forming the adult red blood cell (22). A temporary block in cellular differentiation at an early and highly proliferative stage of development could potentially increase the proliferation capacity of erythroblasts in culture. Temporarily delaying differentiation of the more immature and highly proliferative proerythroblast stage could potentially increase culture expansion capacity.

PU.1, is a transcription factor encoded by the SPI-1/Sfpi gene, and is vital in the regulation of hematopoietic development (23). When over expressed, PU.1 disrupts the differentiation program in erythroblasts (24-26). In the model of murine eryrtholeukemia, the insertion of the Friend spleen focus-forming virus (SFFV) upstream to the transcription start site of the PU.1 gene leads to constitutive expression and to blockage of erythroid cell differentiation (27). Therefore, we theorize that temporary overexpression of PU.1 by transfection will increase in vitro proliferation efficiency of the erythroblasts by blocking differentiation at an immature and highly proliferative state. The overexpression of PU.1 can lead to erythroblast expansion independent of EPO (25). Transfected gene expression can be strategically controlled by an inducible promoter gene such as Tetracycline-Responsive Promoters. Erythroblast differentiation and proliferation could potentially be tightly controlled in vitro through genetic engineering.

\section{Study Methods and Procedures}

The collection of peripheral blood from healthy volun-

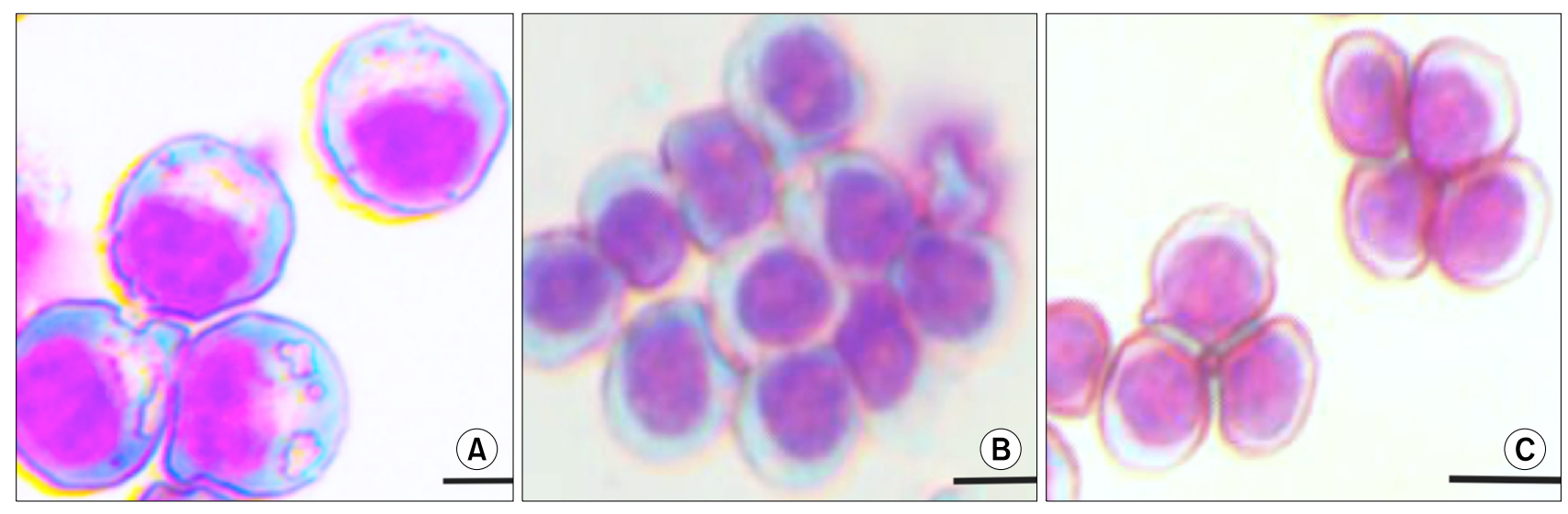

Fig. 1. Stages in the development of erythroblasts. (A) Proerythroblast is the earliest committed stage in erythropoiesis. It is rather large cell $(12 \sim 20 \mu \mathrm{m})$, up to three times a normal erythrocyte. Proerythroblast have large nucleus, and blue cytoplasm that forms a thin rim around the nucleus. The chromatin is granular and stripped. The nucleus have multiple nucleoli. Proerythroblast have small pale area adjacent to the nucleus that corresponds to the Golgi apparatus and have a characteristic pale perinuclear halo. (B) Polychromatophilic Normoblast is smaller $(12 \sim 15 \mu \mathrm{m})$ then the proerythroblast. Hemoglobin in the cytoplasm reduces the basophilia of the cytoplasm. The chromatin shows a greater degree of clumping and irregular dense areas of staining are seen in the nucleus. (C) Orthochromatophilic Normoblast is smaller $(8 \sim 12 \mu \mathrm{m})$ than the polychromatophilic normoblast The cytoplasm has the same color as a mature erythrocyte. The orthochromatophilic normoblast is the nucleated erythroid precursor. Scale bar $10 \mu \mathrm{m}$. 
teers was approved by the Santa Barbara Cottage Health Institutional Review Board for Human Sample-Based Experiments. All studies involving the use of human samples were conducted in accordance with the Declaration of Helsinki and the Santa Barbara Cottage Health Institutional Review Board.

Circulating adult HSCs were isolated from whole blood samples by treatment with a tetrameric antibody cocktail Human Hematopoietic Progenitor Cell Enrichment Cocktail (Stem Cell Technologies, Vancouver, Canada). The tetrameric antibodies conjugate cells expressing surface antigens associated with differentiated cells lines. Adult stem cells within the sample were isolated through negative selection. Blood samples were purified through centrifugation density gradient ( $\rho 1.077 \mathrm{mg} / \mathrm{mL}$ ) at $1,200 \mathrm{~g}$ for 20 minutes, according to the manufacturer's recommendations (Stem Cell Technology). The purified HSCs were washed in phosphate buffered saline (PBS). The cells were seeded in a liquid suspension culture system described below.

\section{Generation and expansion of HSCs derived erythroblasts}

Purified mononuclear cells containing $\mathrm{CD}_{3}{ }^{+}$and CD34 ${ }^{-}$HSCs were seeded in a liquid growth media containing alpha $\mathrm{MEM}^{\mathrm{TM}}$, Fetal Bovine Serum (Heat inactivated US origin) 20\% (both from Life Technologies, Carlsbad CA), with interleukin-3 (IL-3) $10 \mathrm{ng} / \mathrm{mL}$, recombinant human EPO $6 \mathrm{u} / \mathrm{mL}$, SCF $10 \mathrm{ng} / \mathrm{mL}$, and Insulin like Growth Factorl (IGF-1) $10 \mathrm{ng} / \mathrm{mL}$ (all from PeproTech, Rocky Hill NJ), Chem Defined Lipid 0.5\%, Dexamethasone $1 \mu \mathrm{M}$ and Estradiol $1 \mu \mathrm{M}$ (Sigma-Aldrich, St Louis MO). The culture was maintained at $37^{\circ} \mathrm{C}$, in high humidity, pCO2 5\%, and pO2 5\%. On culture day 10, cells were transfected with Plasmid DNA.

\section{Plasmid DNA Vector Construction}

Two vector constructs were used to transfect HSCs derived erythroblast on day 10 . The primary expression vector was a PiggyBac (PB) transposon vector construct pPBCMV:SPI-1: IRES: hrGFP. Expression of the transfected genes from this vector enables transcription of the SPI-1 and a humanized form of the green fluorescent protein. The second vector was the helper plasmid pPB-Puro-CAGG-Pbase encoding the PB transposase that has been described previously $(28,29)$. Expression of the transfected genes from this vector enables transcription of the $\mathrm{PB}$ transposase and puromycin resistance. Plasmid cloning services were obtained through Cyagen Biosciences, Santa Clara, CA.

\section{Cell Transfections}

On day 10, HSC derived erythroblasts were washed in PBS and $1 \times 10^{6}$ cells were suspended in $400 \mu \mathrm{L}$ Ingenio solution (Mirusbio, Madison, WI) containing plasmid DNA at concentrations of $20 \mu \mathrm{g} / \mathrm{mL}$ (PB) transposon vector and $20 \mu \mathrm{g} / \mathrm{mL}$ PB transposase. Cell solutions were transfected by electroporation with Gene Pulser Xcell ${ }^{\mathrm{TM}}$ (Bio-Rad, Hercules, CA). Cell solutions were pulsed with square waves of $220 \mathrm{~V}$ for $38 \mathrm{~ms}$ according to manufacturer's published instructions. Cells were immediately transferred to 24 well plate, suspended in liquid growth media, and maintained at $37^{\circ} \mathrm{C}$ in high humidity: pCO2 $5 \%$ and $\mathrm{pO} 25 \%$.

\section{Cell Culture and Treatments}

Post transfection, cells were maintained in growth media containing alpha $\mathrm{MEM}^{\mathrm{TM}}$, Fetal Bovine Serum (Heat inactivated US origin) 20\%, interleukin-3 (IL-3) $10 \mathrm{ng} / \mathrm{mL}$, recombinant human EPO $6 \mu / \mathrm{mL}$, SCF $10 \mathrm{ng} / \mathrm{mL}$, and IGF-1 40 ng/mL (all from PeproTech, Rocky Hill, NJ), Chem Defined Lipid 0.5\%, Dexamethasone $1 \mathrm{uM}$ and Estradiol $1 \mu \mathrm{M}$ (Sigma-Aldrich, St Louis MO). Partial growth media changes were preformed daily for 10 days then every 3 days for up to 45 days. Forty-eight hours after electroporation, puromycin $(0.5 \mathrm{mg} / \mathrm{mL})$ was added to the growth media. Cells successfully transfected would express the puromycin resistance gene and survive in the presence of puromycin, while cells not transfected would not survive in the presence of puromycin, purifying the transfected cells in culture.

Cells were analyzed in vitro under an Olympus phase contrast microscope, and fluorescence microscopy. Cell contrast was achieved using May-Grunwald/Giemsa. Cells were counted using an automated hemocytometer. The cells were analyzed by FACS immunophenotyping, performed at the Santa Barbara Cottage Hospital Flow Cytometry laboratory.

\section{Results}

\section{Hematopoietic Stem Cell derived erythroblasts}

The HSC derived erythroblasts were analyzed by confocal phase contrast microscopy with May Grunwald/Giemsa staining. The cultured cells demonstrated characteristic features of maturing erythroblasts.

\section{Transfection efficiency}

PB transfection of the immature erythroblasts was achieved through coelectroporation of the two plasmids, PB transposon and the PB transposase. The transfection effi- 
ciency approached 10\% of cells surviving electroporation. Successful transfection was determined by green fluorescence under microscopy expressed by the GFP reporter gene (Fig. 2). To purify the transfected cells, 2 days after electroporation, puromycin was added to the culture to induce cell death in cells that were not transfected and expressing the puromycin resistance gene. For the following three days, there was significant cell death and debris. Cell cultures were washed daily.

\section{Erythropoiesis efficiency and immortalization of transfected erythroblasts}

Ten day old erythroblasts were transfected by electroporation with plasmid DNA. The erythroblast cell cultures were counted every three to five days with a Countess ${ }^{\circledR}$ Automated Cell Counter. Transfected cells surviving puromycin negative selection continued to proliferate through 45 days in culture suggesting the cells have been immortalized.

\section{Transfected erythroblast immunophenotyping by Flow cytometry}

Transfected erythroblasts were evaluated by Flow cytometry (FC) analysis to determine immunophenotyping identification of the erythroblast and state of differentiation. Cells were immunophenotypically analyzed for the presence of CD71, CD117 and CD235a, demonstrated in Fig. $3 \sim 5$. CD71 is the transferrin receptor molecule and is re-
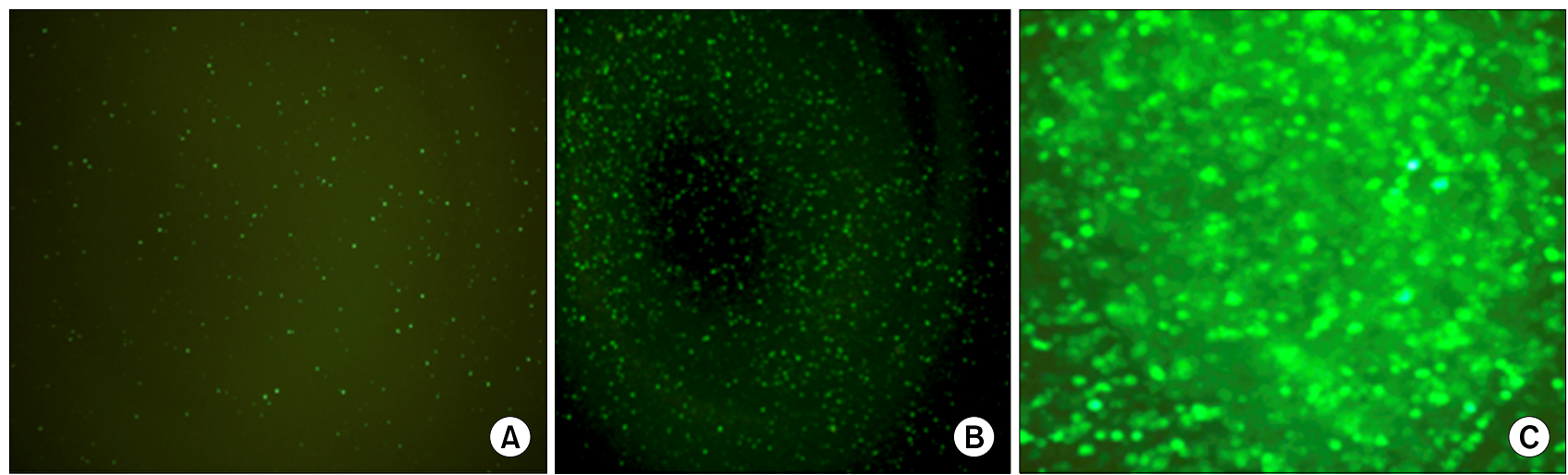

Fig. 2. Fluorescence micrographs of HSC derived erythroblasts after electroporation. (A) 48 hours after electroporation. (B) 96 hours after electroporation. (C) 96 hours after electroporation.

A

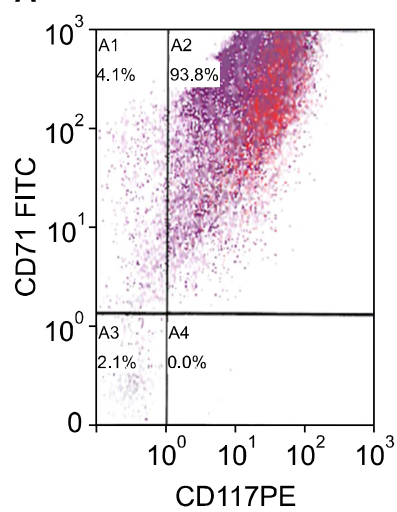

B

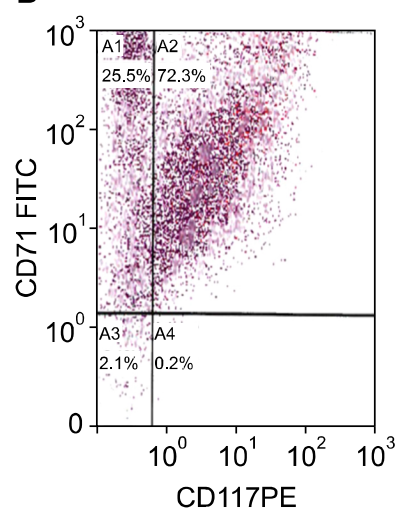

C

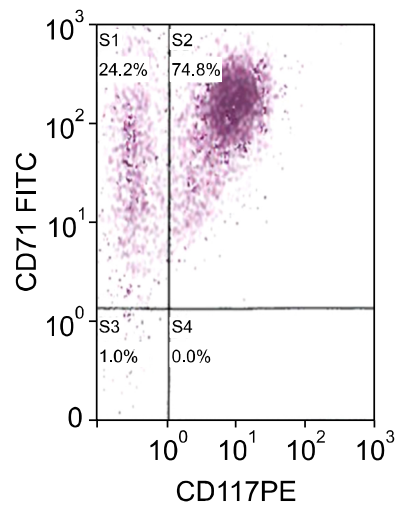

D

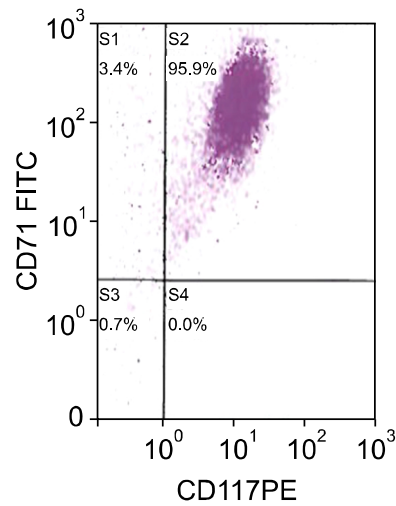

Fig. 3. Flow cytomtery analysis. Serial phenotypic analysis by FC anaylsis of HSC derived erythroblast of a control culture compared to genetically enhanced HSC derived erythroblast. By day 41 , almost all of the detectable cells $(95.9 \%)$ analyzed appeared to be CD71 ${ }^{+}$ $\mathrm{CD} 117^{+}$, in a pattern that could be consistent with one population of very similar early proerythroblasts. (D) CD117 is the Stem Cell Factor receptor and expressed at the earliest pro-erythroblast stage. CD71 is the transferrin receptor and is strongly expressed in all cells erythroid precursors. (A) Erythroblast culture day 10. (B) Erythroblast culture day 14, control. (C) Genetically enhanced erythroblasts culture day 14 , and 3 days after transfection with PU.1/SPI-1 gene. (D) Genetically enhanced erythroblasts culture day 41 , and 30 days after transfection with PU.1/SPI-1 gene. 
A

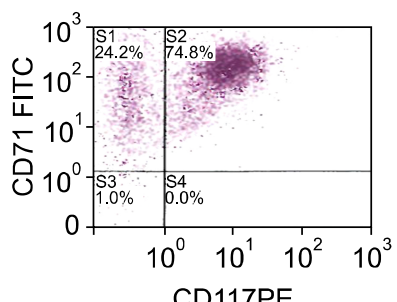

B

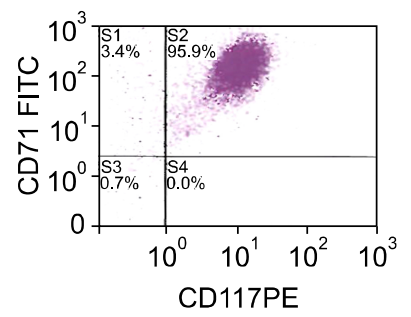

Fig. 4. (A) Erythroblast culture post, transfection day \#3, culture day $\# 14$, (B) Erythroblast culture control, transfection day \#30, culture day \#41.

A

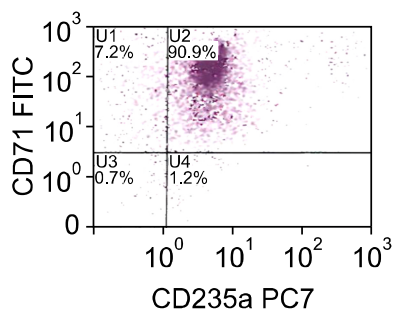

B

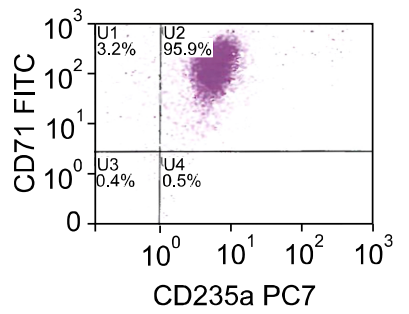

Fig. 5. (A) Erythroblast culture post, transfection day \#3, culture day $\# 14$, (B) Erythroblast culture control, transfection day \#30, culture day \#41.

sponsible for iron uptake into the erythroblast. CD71 is highly expressed in the early erythroblast, but is down-regulated as the cells pass the basophilic erythroblast stage (30). CD117 is the c-kit/Stem Cell Factor receptor and is present on immature progenitor cells, but lost as cells differentiate. CD117 is expressed at the earliest proerythroblast stage (31). $\mathrm{CD} 117^{+} \mathrm{CD} 71^{+}$erythroblasts are early proerythroblasts. CD235a is the glycophorin A antigen, and is expressed in all erythroid cells in nearly all stages of differentiation from erythroblasts to mature erythrocytes (32).

On culture day 10, FC analysis of the control culture of HSC derived erythroblasts demonstrated $93.8 \%$ of the cells were $\mathrm{CD} 71^{+} \mathrm{CD} 117^{+}$(Fig. 3A). By culture day 14, $\mathrm{CD} 71^{+}$ $\mathrm{CD}_{11} 7^{+}$cells represented only $72.3 \%$ of the cells, indicating the cells had matured with $25.5 \%$ of cells having lost the expression of the CD117 (Fig. 3B). On culture day 14 of the transfected cells, 3 days after electroporation, a similar amount of cells, $74.8 \%$, retained the $\mathrm{CD} 71^{+} \mathrm{CD} 117^{+}$ expression. (Fig. 4A) Interestingly, by culture day 41, 30 days after electroporation, $95.9 \%$ of cells were $\mathrm{CD} 71^{+}$ $\mathrm{CD} 117^{+}$, representing a single population of cells transfected with the SPI-1 gene (Fig. 5B). The overexpressing of the SPI-1/PU.1 appeared to hold the cells in a less differentiated, immature proerythroblast stage. Between cul-

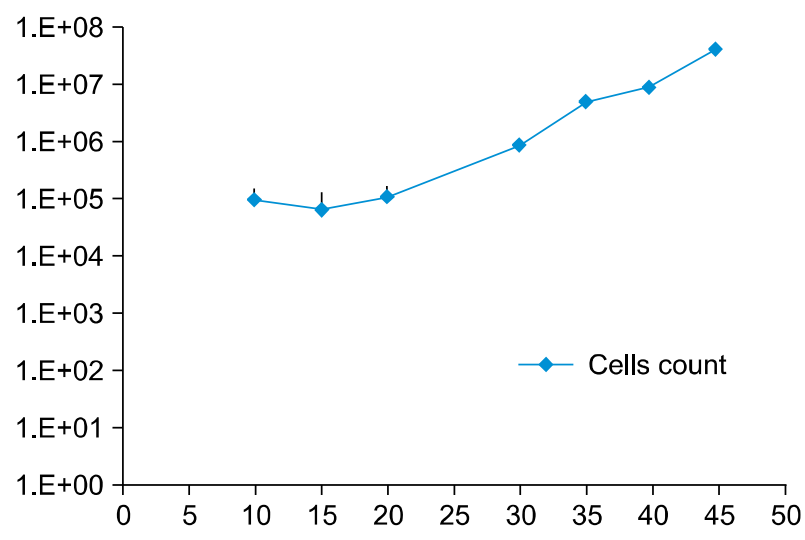

Fig. 6. Erythroblast cells count average of three experiments.

ture day 14 and day 41, CD235a expression had increased by $4.8 \%$. The cells continued to expand through culture day 45 (Fig. 6). The control culture proliferation slowed by culture day 20 and the culture became unviable by day 25.

\section{Discussion}

In this study, we transfected HSC derived erythroblasts with electroporation to create a population of erythroblasts overexpressing the transcription factor PU.1. The engineered population of cells was intended to mimic, in vitro, the highly proliferative erythroblasts of murine leukemia in which the insertion of the Friend SFFV, upstream to the transcription start site of the PU.1 gene, leads to constitutive expression of PU.1 and to the blockage of erythroid cell differentiation (27). The FACS analysis suggests a single population of transfected cells that were immature proerythroblasts, likely resulting from overexpression of PU.1.

PU.1 is known to be a regulator of the proliferation and differentiation of erythroid cell line (33). It is well known that aberrant JAK2 STAT signaling produced by the Janus kinase 2 (JAK2) V617F mutation is associated with both polycythemia vera (PV), and essential thrombocythemia (ET) in a dose dependent manner. Patients with PV have a homozygous JAK2 V617F mutation, and patients with ET have a heterozygous mutation, indicating the dose dependent effect of the mutation (34). The JAK2 V617F mutation has been shown to upregulate PU.1 in vitro (35). It has been demonstrated that PU.1 is regulated by GATA-1, SpiB, Oct-1, Spl, and by PU.1 itself (33). The target genes of PU.1 include those encoding IL-7 receptor a (IL-7Ra), macrophage colony stimulating factor receptor (M- CSFR), G-CSF receptor (G-CSFR), and granulocyte mac- 
rophage colony stimulating factor receptor a (GM-CSFRa) (36).

An inducible expression system such as a tetracycline transactivator (tTA) protein (37) could potentially be incorporated into the plasmid DNA in order to turn off the overexpression of PU.1 and allow the cultured erythroblast to differentiate into mature erythrocytes.

The mass production of red blood cells necessary to reach clinically relevant quantities, near the trillion cell level present in a transfusion, will require significant advancement in erythroblast proliferation capacity in culture. We theorize here that barriers to mass production of erythroid cells may be overcome through genetic engineering of erythroid progenitor cells, inducing an immature yet highly proliferative state. Genetic manipulation would appear to represent one avenue for reaching the trillion-cell level.

In summary, the transfection of human erythroblasts with the PU.1/SPI-1 gene appears to, at least temporarily immortalize immature proerythroblast cells and enhance proliferation. Although the concept of genetically enhanced in vitro erythropoiesis is compelling, further studies are necessary to prove equivalence with in vivo derived erythrocytes. The temporary overexpression of PU.1 could result in erythrocytes with abnormal physical characteristics. Given the block in maturation induced by the PU.1, it is possible that these transfected cells may be unable to complete the maturation cycle resulting in the enucleation of the modified nucleus. Overexpression of PU.1 may alter the formation of hemoglobin. Future investigations should characterize protein levels with western blot analysis compared to non transfected cells at the same maturation state. Hemoglobin content and typing should be investigated in the transfected cells.

\section{Acknowledgments}

We are grateful to the Santa Barbara Cottage Hospital Flow Cytometry laboratory for providing Fluorescence-activated cell sorting services and to our colleagues in the Flow cytometry lab for technical support. This research project was supported by a grant from Santa Barbara Cottage Hospital, Santa Barbara California. We are grateful to the Institutional Review Board at Santa Barbara Cottage Health Systems for their oversight in our human studies.

\section{Potential conflict of interest}

The authors have no conflicting financial interest.

\section{References}

1. The 2007 National Blood Collection and Utilization Survey Report. Washington, DC: DHHS; 2008.

2. Benjamin RJ, Whitaker BI. Boom or bust? Estimating blood demand and supply as the baby boomers age. Transfusion 2011;51:670-673

3. Surgenor DM, Wallace EL, Hao SHS, Chapman RH. Collection and transfusion of blood in the United States, 1982-1988. N Engl J Med 1990;322:1646-1651

4. Wallace EL, Surgenor DM, Hao HS, An J, Chapman RH, Churchill WH. Collection and transfusion of blood and blood components in the United States, 1989. Transfusion 1993;33:139-144

5. Wallace EL, Churchill WH, Surgenor DM, An J, Cho G, McGurk S, Murphy L. Collection and transfusion of blood and blood components in the United States, 1992. Transfusion 1995;35:802-812

6. Sullivan MT, McCullough J, Schreiber GB, Wallace EL. Blood collection and transfusion in the United States in 1997. Transfusion 2002;42:1253-1260

7. Sullivan MT, Wallace EL. Blood collection and transfusion in the United States in 1999. Transfusion 2005;45:141-148

8. Blood Facts and Statistics. American Red Cross [Internet]. Available from: www.redcrossblood.org/learn-about- blood/ blood-facts-and-statistics.

9. Geiler C, Andrade I, Greenwald D. Exogenous c-Myc blocks differentiation and improves expansion of human erythroblasts in vitro. Int J Stem Cells 2014;7:153-157

10. Migliaccio G, Di Pietro R, di Giacomo V, Di Baldassarre A, Migliaccio AR, Maccioni L, Galanello R, Papayannopoulou $\mathrm{T}$. In vitro mass production of human erythroid cells from the blood of normal donors and of thalassemic patients. Blood Cells Mol Dis 2002;28:169-180

11. Giarratana MC, Rouard H, Dumont A, Kiger L, Safeukui I, Le Pennec PY, François S, Trugnan G, Peyrard T, Marie T, Jolly S, Hebert N, Mazurier C, Mario N, Harmand L, Lapillonne H, Devaux JY, Douay L. Proof of principle for transfusion of in vitro-generated red blood cells. Blood 2011;118:5071-5079

12. Leberbauer C, Boulmé F, Unfried G, Huber J, Beug H, Müllner EW. Different steroids co-regulate long-term expansion versus terminal differentiation in primary human erythroid progenitors. Blood 2005;105:85-94

13. da Silva CL, Gonçalves R, Crapnell KB, Cabral JM, Zanjani ED, Almeida-Porada G. A human stromal-based serum-free culture system supports the ex vivo expansion/ maintenance of bone marrow and cord blood hematopoietic stem/progenitor cells. Exp Hematol 2005;33:828-835

14. Miharada K, Hiroyama T, Sudo K, Nagasawa T, Nakamura Y. Efficient enucleation of erythroblasts differentiated in vitro from hematopoietic stem and progenitor cells. Nat Biotechnol 2006;24:1255-1256

15. Fujimi A, Matsunaga T, Kobune M, Kawano Y, Nagaya T, Tanaka I, Iyama S, Hayashi T, Sato T, Miyanishi K, Sagawa T, Sato Y, Takimoto R, Takayama T, Kato J, Gasa 
S, Sakai H, Tsuchida E, Ikebuchi K, Hamada H, Niitsu Y. Ex vivo large-scale generation of human red blood cells from cord blood CD34+ cells by co-culturing with macrophages. Int J Hematol 2008;87:339-350

16. Dahlberg A, Delaney C, Bernstein ID. Ex vivo expansion of human hematopoietic stem and progenitor cells. Blood 2011;117:6083-6090

17. Majka M, Janowska-Wieczorek A, Ratajczak J, Ehrenman K, Pietrzkowski Z, Kowalska MA, Gewirtz AM, Emerson SG, Ratajczak MZ. Numerous growth factors, cytokines, and chemokines are secreted by human CD34 $(+)$ cells, myeloblasts, erythroblasts, and megakaryoblasts and regulate normal hematopoiesis in an autocrine/paracrine manner. Blood 2001;97:3075-3085

18. Zamai L, Secchiero P, Pierpaoli S, Bassini A, Papa S, Alnemri ES, Guidotti L, Vitale M, Zauli G. TNF-related apoptosis-inducing ligand (TRAIL) as a negative regulator of normal human erythropoiesis. Blood 2000;95:3716-3724

19. Richmond TD, Chohan M, Barber DL. Turning cells red: signal transduction mediated by erythropoietin. Trends Cell Biol 2005;15:146-155

20. Lodish H, Flygare J, Chou S. From stem cell to erythroblast: regulation of red cell production at multiple levels by multiple hormones. IUBMB Life 2010;62:492-496

21. Stephenson JR, Axelrad AA, McLeod DL, Shreeve MM. Induction of colonies of hemoglobin-synthesizing cells by erythropoietin in vitro. Proc Natl Acad Sci U S A 1971; 68:1542-1546

22. Nathan DG, Chess L, Hillman DG, Clarke B, Breard J, Merler E, Housman DE. Human erythroid burst-forming unit: T-cell requirement for proliferation in vitro. J Exp Med 1978;147:324-339

23. Burda P, Laslo P, Stopka T. The role of PU.1 and GATA-1 transcription factors during normal and leukemogenic hematopoiesis. Leukemia 2010;24:1249-1257

24. Cook WD, McCaw BJ, Herring C, John DL, Foote SJ, Nutt SL, Adams JM. PU.1 is a suppressor of myeloid leukemia, inactivated in mice by gene deletion and mutation of its DNA binding domain. Blood 2004;104:3437-3444

25. Barnache S, Wendling F, Lacombe C, Denis N, Titeux M, Vainchenker W, Moreau-Gachelin F. Spi-1 transgenic mice develop a clonal erythroleukemia which does not depend on p53 mutation. Oncogene 1998;16:2989-2995

26. Moreau-Gachelin F, Wendling F, Molina T, Denis N, Titeux M, Grimber G, Briand P, Vainchenker W, Tavitian
A. Spi-1/PU.1 transgenic mice develop multistep erythroleukemias. Mol Cell Biol 1996;16:2453-2463

27. Ruscetti SK. Deregulation of erythropoiesis by the Friend spleen focus-forming virus. Int J Biochem Cell Biol 1999;31:1089-1109

28. Chew SK, Rad R, Futreal PA, Bradley A, Liu P. Genetic screens using the piggyBac transposon. Methods 2011;53: 366-371

29. Wang W, Lin C, Lu D, Ning Z, Cox T, Melvin D, Wang X, Bradley A, Liu P. Chromosomal transposition of PiggyBac in mouse embryonic stem cells. Proc Natl Acad Sci U S A 2008;105:9290-9295

30. Brendt P, Rehfeld I, Kamphausen A, Kreissig C, Peters J. Lipopolysaccharide interference in erythropoiesis in mice. Anaesthesia 2012;67:493-500

31. Fajtova M, Kovarikova A, Svec P, Kankuri E, Sedlak J. Immunophenotypic profile of nucleated erythroid progenitors during maturation in regenerating bone marrow. Leuk Lymphoma 2013;54:2523-2530

32. Erber WN, McLachlan J, Cordell JL, Turley H, Reid M, Mason DY. A new monoclonal antibody (JC159) that detects glycophorin A for the diagnosis of erythroleukaemia. Hematol Rev 1991;5:113-120

33. Gupta P, Gurudutta GU, Saluja D, Tripathi RP. PU.1 and partners: regulation of haematopoietic stem cell fate in normal and malignant haematopoiesis. J Cell Mol Med 2009; 13:4349-4363

34. Jones AV, Kreil S, Zoi K, Waghorn K, Curtis C, Zhang L, Score J, Seear R, Chase AJ, Grand FH, White H, Zoi C, Loukopoulos D, Terpos E, Vervessou EC, Schultheis B, Emig M, Ernst T, Lengfelder E, Hehlmann R, Hochhaus A, Oscier D, Silver RT, Reiter A, Cross NC. Widespread occurrence of the JAK2 V617F mutation in chronic myeloproliferative disorders. Blood 2005;106:2162-2168

35. Irino $T$, Uemura $M$, Yamane $H$, Umemura $S$, Utsumi $T$, Kakazu N, Shirakawa T, Ito M, Suzuki T, Kinoshita K. JAK2 V617F-dependent upregulation of PU.1 expression in the peripheral blood of myeloproliferative neoplasm patients. PLoS One 2011;6:e22148

36. Fisher RC, Slayton WB, Chien C, Guthrie SM, Bray C, Scott EW. PU.1 supports proliferation of immature erythroid progenitors. Leuk Res 2004;28:83-89

37. Gossen M, Bujard H. Tight control of gene expression in mammalian cells by tetracycline-responsive promoters. Proc Natl Acad Sci U S A 1992;89:5547-5551 